\title{
Recurrent Subcutaneous Panniculitis-Like T-Cell Lymphoma
}

National Cancer Institute

\section{Source}

National Cancer Institute. Recurrent Subcutaneous Panniculitis-Like T-Cell Lymphoma. NCI Thesaurus. Code C157695.

The reemergence of subcutaneous panniculitis-like T-cell lymphoma after a period of remission. 